\title{
Progresszív kórlefolyást mutató szisztémás mastocytosis
}

\author{
Várkonyi Judit dr. ${ }^{1}$ - Szombath Gergely dr. ${ }^{1}$ - Vályi-Nagy Anna dr. ${ }^{1}$ \\ Csomor Judit dr. ${ }^{2}$. Egedi Krisztina dr. ${ }^{2}$ - Kovalszky Ilona dr. ${ }^{2}$ \\ Tölgyesi Katalin dr. ${ }^{3}$ - Szerafin László dr. ${ }^{3}$ \\ Tóth László dr. ${ }^{4}$ - Soós Györgyi dr. ${ }^{4}$ - Masszi Tamás dr. ${ }^{1}$ \\ Semmelweis Egyetem, Általános Orvostudományi Kar, \\ ${ }^{1}$ III. Belgyógyászati Klinika, ${ }^{2}$ I. Patológiai Intézet, Budapest \\ ${ }^{3}$ Jósa András Oktató Kórház, Hematológiai Osztály és Patológia Osztály, Nyíregyháza \\ ${ }^{4}$ Debreceni Egyetem, Általános Orvostudományi Kar, Patológiai Intézet, Debrecen
}

\begin{abstract}
A szerzők egy kiterjedt bőrérintettséggel járó szisztémás mastocytosisban szenvedő férfi beteg esetének bemutatásán keresztül rövid összefoglalót adnak erről a ritka kórformáról. A beteg életminőségét megkeserítő krónikus hasmenés antihisztaminok, a mellkascsapolás után korábban visszatermelődő folyadékgyülem alfa-interferon alkalmazása mellett megszűnt. Mintegy 40 évvel a bőrtünetek jelentkezését követően mind a „B” (30\%-nál nagyobb mértékű csontvelő-infiltráció, dismyelopoesis, triptázszint $>20 \mu \mathrm{g} / \mathrm{L}$, máj- és lépmegnagyobbodás), mind pedig a „C” tünetek megjelenése (kóros májfunkció, cytopeniák, malabszorpciós tünetek, osteoporosis) jelezte a progressziót, és a beteg 87 éves korában exitált.

A szerzők esetismertetésükkel felhívják a figyelmet erre a ritka betegségre és hangsúlyozzák, hogy a betegek számára tüneti, illetve egyedi méltányossági kérelem útján elérhető szerekkel jobb életminőség érhető el.
\end{abstract}

Orv Hetil. 2018; 159(5): 192-196.

Kulcsszavak: mastocytosis, mellkasi folyadékgyülem, krónikus hasmenés

\section{Systemic mastocytosis with progressive disease course}

Authors report on a case of a male patient of systemic mastocytosis that was associated with extensive cutaneous lesions. Chronic diarrhoea worsening his quality of life was well managed by the administration of antihistamines. The pleural fluid recurrence soon after drainage has been controlled by the administration of alpha interferon.

40 years after the onset of the first skin signs progression has been manifested in the development of " $B$ " (bone marrow infiltration rate $>30 \%$, dysmyelopoiesis, serum tryptase $>20 \mu \mathrm{g} / \mathrm{L}$, hepato- and splenomegaly) and "C" symptoms (liver function test abnormalities, cytopenia, malabsorption, osteoporosis). The patient died at age of 87.

The authors' aim was to attract attention on this rare disease and emphasize that symptomatic therapy with antihistamines and drugs available based on customised rights by the National Health Insurance Fund might provide good quality of life.

Keywords: mastocytosis, pleural fluid, chronic diarrhoea

Várkonyi J, Szombath G, Vályi-Nagy A, Csomor J, Egedi K, Kovalszky I, Tölgyesi K, Szerafin L, Tóth L, Soós Gy, Masszi T. [Systemic mastocytosis with progressive disease course]. Orv Hetil. 2018; 159(5): 192-196.

(Beérkezett: 2017. október 27.; elfogadva: 2017. november 23.)

\section{Rövidítések}

ASM = agresszív szisztémás mastocytosis; $\mathrm{c}-\mathrm{KIT}=$ stem cell factor receptor; $\mathrm{DNS}=$ dezoxiribonukleinsav; $\mathrm{Hl}=$ hisztamin 1-receptor; H2 = hisztamin-2-receptor; $\mathrm{HE}=$ hematoxilin-eozin festés; ISM = indolens szisztémás mastocytosis; $\mathrm{MC}=$ mas- tocyta PUVA = psoralen + ultraviola „A” sugár; SAP = szérum alkalikus foszfatáz; $\mathrm{SCF}=$ stem cell factor; $\mathrm{SM}=$ szisztémás mastocytosis; SSM = (smoldering systemic mastocytosis) lappangó szisztémás mastocytosis; $\mathrm{WHO}=$ World Health Organization 
A mastocytosis egy ritka, a hízósejtek kóros mértékü felszaporodásával és/vagy kóros aktiválódásával jellemezhető megbetegedés, melynek hátterében az ún. stem cell factor (SCF) KIT receptorát kódoló c-KIT gén mutációja (többnyire a D816V) mutatható ki (1. táblázat). A betegség WHO-klasszifikációja szerint (2. táblázat) megkülönböztetünk csak bőrre terjedő, illetve szisztémás megbetegedés formákat, de létezik a csak hízósejtaktivációs tünetekkel rendelkező kategória is [1]. Ismert a három forma kombinációja is akár kezdettől, vagy a betegség progressziója során jelentkezve.

A jelátviteli útvonal mutáció következtében bekövetkezett diszregulációja következtében morfológiailag és funkcionálisan is megváltozott hízósejtek mutathatók ki az érintett szervból (ez leginkább a csontvelő) származó szövettani mintában immunhisztokémiai és áramlási citometriás módszerekkel egyaránt [2]. Vérmintából a vérkép, a szérumtriptáz és a szérum alkalikus foszfatáz (SAP) bír prognosztikai jelentőséggel [3]. Mindezek alapján megkülönböztethetünk a kórlefolyás tekintetében indolens (ISM), lappangó (SSM) vagy agresszív (ASM) formákat [4].

Az ASM esetében a csontvelőt beszürő hízósejtek orsóformát öltenek, esetenként örvénylő mintázatot mutatnak, gyakorta van jelen eosinophilia. A hízósejt-infilt-

1. táblázat | Diagnosztikus kritériumok

A szisztémás mastocytosis diagnosztikus kritériumai
Major

Multifokális mastocyta (MC)-infiltrációk a csontvelőben, vagy más extracutan szervben több mint 15 MC képezte aggregátum

Minor

Az infiltráló MC-k > 25 \%-ban a normálistól eltérő, orsószerü morfológiát mutatnak

c-KIT 816 kodon mutációja kimutatható a vérben, a csontvelőben vagy az érintett szervben

A MC-k CD2- és/vagy CD25-koexpressziót mutatnak

A szérumtriptáz $>20 \mu \mathrm{g} / \mathrm{L}$

SM-diagnózis = 1 major +1 minor kritérium

vagy

SM-diagnózis = 3 minor kritérium

\section{2. táblázat | WHO-klasszifikáció, 2016}

A mastocytosis WHO-osztályozása, 2016

Cutan mastocytosis (CM)

Indolens szisztémás mastocytosis (ISM)

Lappangó (smoldering) szisztémás mastocytosis (SSM)

Szisztémás mastocytosis hematológiai neoplasiával (SM-AHN)

Aggresszív szisztémás mastocytosis (ASM)

Hízósejtes leukaemia (MCL)

Hízósejtes sarcoma (MCS

Extracutan mastocytoma ráció máj- és lépmegnagyobbodást okoz, és a csont érintettsége révén csontsűrüség-csökkenés is igazolható. A betegséget általában jellemző szisztémás tünetek ASM-ben súlyos formában jelentkeznek, gyakoriak a patológiás fracturák [2]. Ritkán bőrtünet nélkül áll fenn, ami nehezíti a felismerést. A laboratóriumi paraméterek is jól tükrözik a súlyos szervi infiltrációt: gyakori a kóros májmúködés és a csontvelő-infiltráció következtében kialakuló vérzékenység, mely thrombocítaszám-csökkenésből, alacsony faktorszintből eredhet. A szérumtriptáz-szint mindig magas.

\section{Esetismertetés}

A 81 éves férfi beteg anamnéziséből magas vérnyomás, ischaemiás szívbetegség miatti gyógyszeres kezelés, világossejtes veserák miatt bal oldali nephrectomia emelendő ki. A beteg 40 éves kora óta ismertek testszerte megjelenő, viszkető bőrelváltozásai, melyet urticaria pigmentosa nodularis formájaként azonosítottak a dermisben Giemsa-festéssel nagy tömegú mastocyta jelenléte alapján. Akkor psoralen + ultraviola „A” sugár (PUVA)kezelésben részesült.

2006-ben jelentkezett krónikus hasmenése, mely tenyésztéssel negatívnak bizonyult, és vastagbél-tükrözés során sem lehetett a makroszkópos kép alapján eltérést ennek hátterében kimutatni. A biopsziás anyagon utólag készült triptáz immunhisztokémiai reakció azonban a submucosában jelen levő hízósejteket igazolt (1. ábra). Helicobacter pylori- és laktózterheléses vizsgálat eltérést nem igazolt. A hasmenés loperamidra nem reagált.

Egy évvel később (2007) többször történt mellkaspunkció a mindig visszatelődő mellüri folyadék miatt, melynek citológiai vizsgálata során malignitásra utaló elváltozás nem igazolódott.

Klinikánkon első alkalommal 2008 februárjában, 81 éves korában jelentkezett macrocytás anaemia, emelkedett SAP, az életét megkeserítő krónikus hasmenések, főként az esti órákra elviselhetetlenné váló viszketés, panaszt okozó hydrothorax és diffúz csontfájdalmak miatt. Fizikális vizsgálata alapján ekkor kiterjedt bőrmanifesztáció és jelentős máj- és lépmegnagyobbodás volt a szembetưnő (2. ábra).

\section{Vizsgálati eredmények}

Az első megjelenéskor vérképe kisfokú eosinophiliát, macrocytás anaemiát és thrombocytopeniát jelzett. $\mathrm{Az}$ anaemia hátterében vas- vagy vitaminhiány nem állt (3. táblázat).

A magas triptázszint kiterjedt megbetegedésre utalt.

Az emelkedett SAP a máj és a csont részvételét is jelezte. Átépült csontszerkezet látszott a humerus rtg-felvételén, de a kórlefolyás során patológiás fractura nem következett be (3. ábra).

A 2009. áprilisban elvégzett oszteodenzitometria jelentősen csökkent csontsưrüséget, fokozott törésrizikót 
A
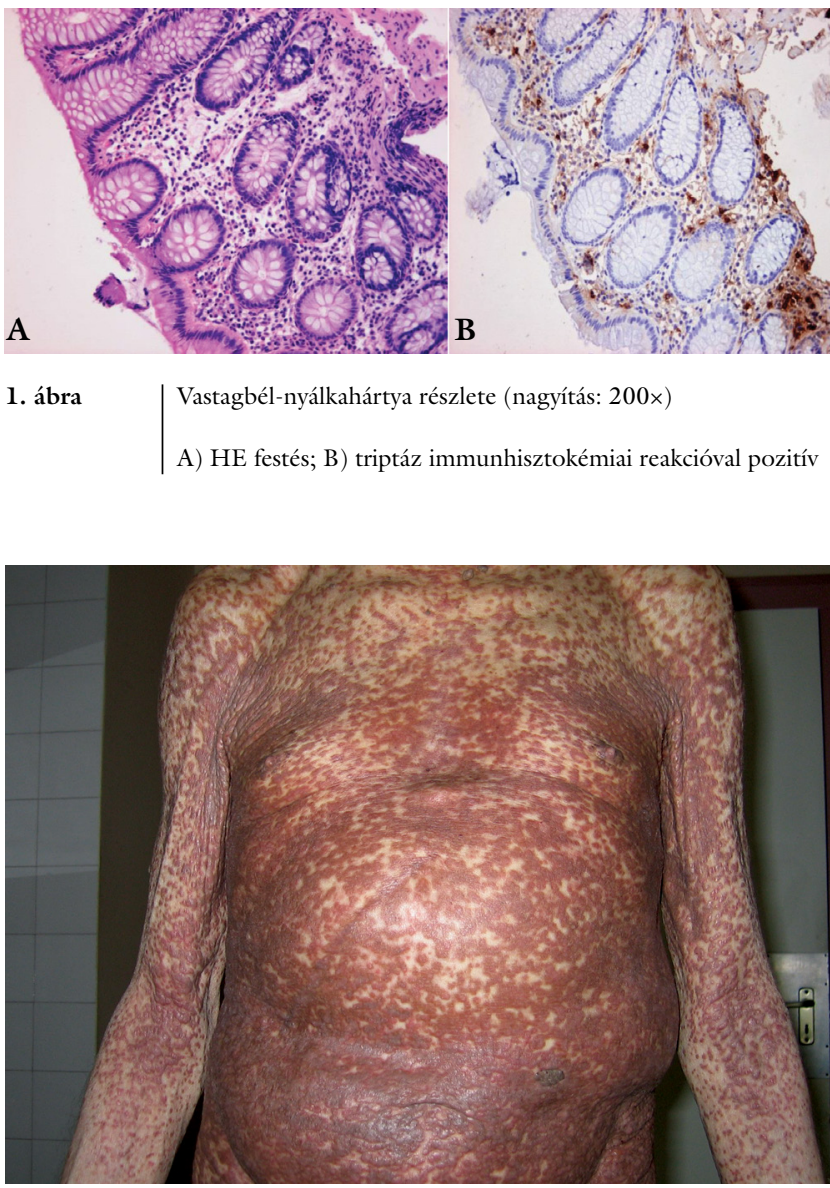

2. ábra

| Urticaria pigmentosa 40 éves fennállás után
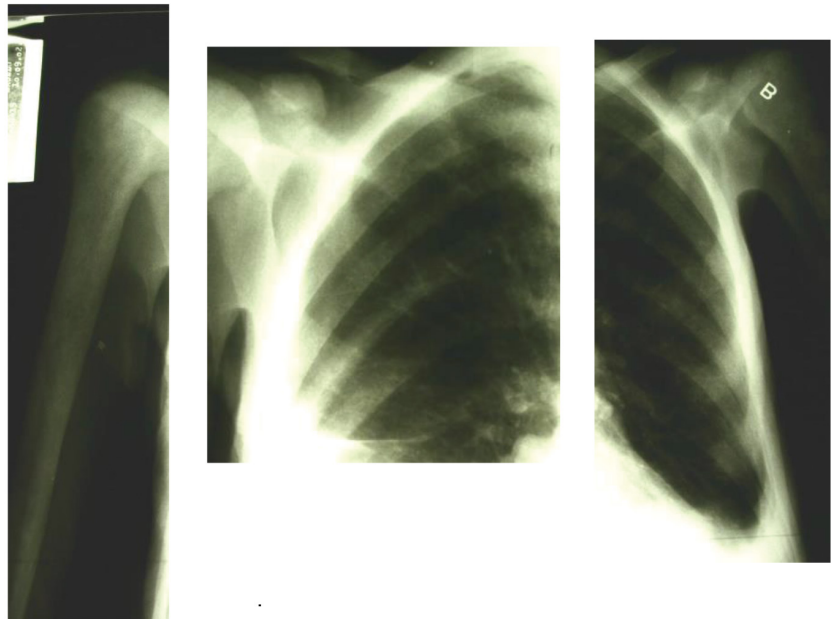

3. ábra

| A felkar átépült csontszerkezete látható a röntgenképen

mutatott: Z-score $-1,71$ és T-score $-3,50$ ultradis; Zscore $-1,32, \mathrm{~T}$-score $-2,92 / \mathrm{Distal}$. A femurnyak $\mathrm{Z}$-score 5,21; T-score 3,14; Ll-L4 Z-score: $+0,30-0,36,-0,02$, $+0,50$, illetve T-score: $-0,43,-1,24,-0,84,-0,36$.

A crista-biopszia gazdagon granulált, kerekded magvú hízósejtes infiltrátumot írt le.
3. táblázat | Laboratóriumi leletek a megjelenéskor és a progresszió időszakában

\begin{tabular}{llll}
\hline $\begin{array}{l}\text { Laboratóriumi } \\
\text { vizsgálatok }\end{array}$ & \multicolumn{2}{c}{ Laboratóriumi leletek } & Referenciaértékek \\
\cline { 2 - 3 } & megjelenéskor $\begin{array}{l}\text { a progresszió } \\
\text { idószakában }\end{array}$ \\
\hline WBC & 7,80 & 11,98 & $4,0-10,0 \times 10^{9} / \mathrm{L}$ \\
Neutrophil sejt & 74 & 60 & $53-75 \%$ \\
Lymphocyta & 10 & 6 & $25-40 \%$ \\
Monocyta & 5 & 2 & $2-10 \%$ \\
Eosinophil & 12 & 33 & $0-5 \%$ \\
RBC & 2,46 & 2,09 & $4,50-5,90 \times 10^{12} / \mathrm{L}$ \\
Hemoglobin & 86 & 73 & $140-175 \mathrm{~g} / \mathrm{L}$ \\
HCT & 0,27 & 0,21 & $0,36-0,48 \mathrm{~L} / \mathrm{L}$ \\
MCV & 109 & 101 & $80-96 \mathrm{fl}$ \\
Thrombocyta & $115 \times 10^{9} / \mathrm{L}$ & 31 & $150-400 \times 10^{9} / \mathrm{L}$ \\
SAP & $150 \mathrm{U} / \mathrm{L}$ & 130 & $40-129 \mathrm{U} / \mathrm{L}$ \\
Se-folsav & 17,5 & - & $6,0-39,7 \mathrm{nmol} / \mathrm{L}$ \\
Se-B ${ }_{12}$-vitamin & 163,9 & - & $145,0-637,0$ \\
Triptáz & 611 & - & $\mathrm{pmol} / \mathrm{L}$ \\
\hline & & $20 \mathrm{ng} / \mathrm{ml}$ \\
\hline
\end{tabular}

Az áramlási citometria vizsgálat 1,7\% CD2-CD25CD117 hármas koexpressziót mutató, szisztémás mastocytosisnak megfelelő sejtek jelenlétét igazolta.

Génszekvenálással a beteg csontvelőből származó dezoxiribonukleinsav (DNS)-mintájában a $c$-KIT gén 17 -es exonján pontmutáció, citozin-timin báziscsere (tranzíció) mutatható ki a 798-as kodonban a 81350-es pozícióban. Ez az ún. csendes, vagyis nem aktiváló mutáció; a c-KIT fehérje aminosavsorrendjében eltérést nem okoz.

\section{Kezelés és kórlefolyás}

A kezelés alfa-interferonnal heti $3 \times 3$ millió egység adagban szubkután alkalmazásban, hisztamin-1 és -2 (H1 és H2)-receptor-blokkolók és kis adag szteroid kiegészítéssel elkezdődött és két éven át tartott. A fenti kezelés mellett a hasmenés megszűnt és a mellűri folyadék sem telődött vissza. A kínzó viszketés megszűnésével a beteg visszanyerte éjszakai nyugalmát.

A beteg 2010. februárban transzfúziót szükségessé tevő anaemia miatt került ismét felvételre. Az alapbetegség progressziójára utaló 40\%-os eosinophilia megjelenése miatt az alfa-interferon-kezelést imatinib napi $50 \mathrm{mg}$ adagjára cseréltük ki. Innentől számítva a transzfúziós igény kéthavonta jelentkezett.

A fulladásos panaszok hátterében ismét visszatelődő hydrothoraxra 2010 szeptemberében derült fény, mely miatt az akkor már fél éve alkalmazott imatinib helyett ismét alfa-interferont kapott. Időközben a thrombocytopenia is fokozódott, melyre a fenntartó dózisnál nagyobb adagú ( $1 \mathrm{mg} / \mathrm{tskg}$ ) szteroidkezelés már hatásta- 
4. táblázat | $\mathrm{A}$ „B” és „C” tünetek definíciója szisztémás mastocytosisban

„B” tünetek (a szöveti infiltráció mércéje)

>30\%-os csontvelőgócos MC infiltrációja vagy

a szérumtriptáz $>20 \mu \mathrm{g} / \mathrm{L}$

MDS/MPN-jellegű eltérések hisztológiai igazolása SM-AHN fennállása nélkül

Organomegalia: hepato-, spleno-, lymphadenomegalia $>2 \mathrm{~cm}$ (UH, CT) a szerv múködésének megtartásával

„C” tünetek (szervi érintettség eredményezte funkciócsökkenés mércéje)

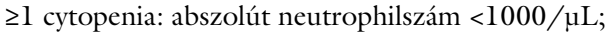

hemoglobin<10 g/dl; thrombocytaszám <100 000/ $\mathrm{LL}$

(a csontvelőfunkció-beszúkülés jeleként)

Kóros májenzimértékek, portalis hypertensio,

ascites (májfunkció-beszúkülés jeleként)

Osteoporosis vagy patológiás fracturák

(csontérintettségből adódóan)

Hypersplenia (lép kóros funkció)

Malabszorpció, krónikus hasmenés, testsúlycsökkenés (bélinfiltrációból eredően)

$\mathrm{MC}=$ mastocyta $; \mathrm{MDS}=$ myelodysplasticus szindróma $; \mathrm{MPN}=$ myeloproliferativ neoplasia; $\mathrm{SM}-\mathrm{AHN}$ = szisztémás mastocytosis hematológiai neoplasiával

lannak bizonyult. Végül csontfájdalmai miatt morfium bevezetésére volt szükség. 87 éves korában, a bőrmanifesztációtól számított 42 . évben exitált.

Az eset tanulságai: A felnőttkorban jelentkező, cutan mastocytosis rendszerint szisztémás betegséggel szövődik. A közel 40 éven át csak bőrtünettel élő betegben a betegség valószínúleg indolens, ún. ISM formájában állhatott fenn, mely azután agresszív formába (ASM) progrediált. A csapolás után is visszatelődő mellüri folyadék, a bőrviszketés és a krónikus hasmenés szisztémás betegség tüneteinek tekinthetők. A szisztémás részvételt igazolja a csontvelő beszűrődése, az ún. „B”, „C” tünetek jelenléte (4. táblázat), beleértve a kórosan emelkedett triptázszintet [5]. Tanulságos továbbá, hogy a betegség bélrendszeri részvétele makroszkóposan nem, csak a biopsziával nyert anyag immunhisztokémiai vizsgálatával igazolható. A beteg kórlefolyásában szereplő világossejtes veserák - a szakirodalomból származó információk szerint - a mastocytosishoz hasonlóan, a c-KIT-mutáció által generált folyamat eredménye lehet [6]. Ezzel függ össze valószínúleg a veserákok alfa-interferon-érzékenysége.

A betegek életminőségén tüneti szerekkel, illetve a már rendelkezésre álló célzott terápiával javítani lehet, a beteg tünet- és panaszmentessé tehető akár több éven át. Az ASM kezelésére a mai tudásunk szerint a cladribin jó hatásfokkal alkalmazható [7].

A beteg esetében észlelt C789T báziscsere nem gyakori mutáció szisztémás mastocytosisban. Ilyen esetben az SM kezelésére külön terápiás javaslat nem áll rendelkezésre. Az alfa-interferon átmenetileg hatásosnak bizo- nyult, azonban a betegség két év után agresszív formába progrediált. Ilyen esetben a klonális evolúció valószínúsíthető, mely végül a betegség terápiarefrakteritását eredményezte. Sajnálatos, hogy ilyen terápia refrakter ASM és hízósejtes leukaemia esetekben a cladribin-, illetve a legújabb ajánlások szerint a tirozinkináz-gátló midostraurin azonnali bevezetésére egyelőre nincs lehetőség.

Orphan betegségrőll lévén szó, ideális esetben a betegek a bőrgyógyásztól hematológushoz kerülnek, majd a csontvelő elemzése, a molekuláris szintű diagnosztika már a centrumokban történik, a minél nagyobb tapasztalatgyưjtés, valamint a betegség célzott terápiájának biztosítása érdekében. Hazánkban az orvosegyetemeken folyik ez a munka. A korai felismerést segíti, ha ezen centrumokban dolgozók a betegség ismertetését széles körben végzik előadások tartása és publikációs tevékenység révén $[8,9]$.

Az európai mastocytosis-hálózat (European Competence Network on Mastocytosis - ECNM) regiszterébe történő csatlakozással bőséges adat gyưlik fel, mely a betegség jobb megismeréséhez vezet [10].

Anyagi támogatás: A közlemény megírása anyagi támogatásban nem részesült.

Szerzői munkamegosztás: V. J., Sz. G., V.-N. A., M. T.: A kézirat megírása. Cs. J.: A patológiai leletezés és a képanyag elkészítése. E. K., K. I.: Molekuláris vizsgálatok. T. K., Sz. L., T. L., S. Gy.: A kórházukban tárolt adatokkal és szövettani képanyaggal járultak hozzá a kézirat összeállításához. A cikk végleges változatát valamennyi szerző elolvasta és jóváhagyta.

Érdekeltségek: A szerzőknek a cikkel kapcsolatban nincs érdekeltségük.

\section{Irodalom}

[1] Valent P, Akin C, Metcalfe DD. Mastocytosis: 2016 updated WHO classification and novel emerging treatment concepts. Blood 2017; 129: 1420-1427.

[2] Pardanani A, Akin C, Valent P. Pathogenesis, clinical features, and treatment advances in mastocytosis. Best Pract Res Clin Haematol. 2006; 19: 595-615.

[3] Horny HP, Sotlar K, Valent P. Mastocytosis: State of the art. Pathobiology 2007; 74: 121-132.

[4] Valent P, Akin C, Escribano L, et al. Standards and standardization in mastocytosis: consensus statement on diagnostics, treatments recommendations and response criteria. Eur J Clin Invest. 2007; 37: 435-453.

[5] Várkonyi J. Systemic mastocytosis. [Szisztémás mastocytosis.] Magyar Bel Arch. 2009; 62: 179-186. [Hungarian]

[6] Krüger S, Sotlar K, Kausch I, et al. Expression of KIT (CD117) in renal cell carcinoma and renal oncocytoma. Oncology 2005; 68: 269-275.

[7] Kluin-Nelemans HC, Oldhoff JM, Van Doormaal JJ, et al. Cladribine therapy for systemic mastocytosis. Blood 2003; 102: $4270-4276$. 
[8] Mihalik N, Hidvégi B, Hársing J, et al. Clinical observations in cutan mastocytosis. [Klinikai tapasztalataink cutan mastocytosisban.] Orv Hetil. 2013; 154: 1469-1475. [Hungarian]

[9] Marton I, Krenács L, Bagdi E, et al. Clinical and molecular diagnostic evaluation of systemic mastocytosis in the South-Eastern Hungarian population between 2001-2013. A single center experience. Pathol Oncol Res. 2016; 22: 293-299.

[10] Várkonyi J. Report on the Annual Meeting of the European Competence Network on Mastocytosis held in Budapest, No- vember 7-8, 2008. [Európa Mastocytosis Hálózati Találkozó Budapesten. Kongresszusi beszámoló.] Hematológia-Transzfúziológia 2008; 41: 173-174. [Hungarian]

(Várkonyi Judit dr., Budapest, Kútvölgyi út 4., 1125 e-mail: varkonyi.judit@med.semmelweis-univ.hu)

\title{
Regöly pályázat - 2018
}

\section{A Professzor Dr. Regöly-Mérei János Alapítvány Kuratóriuma és Szakmai Bizottsága nyolcadik alkalommal hirdet pályázatot.}

\author{
A díjazottak kategóriái \\ 1. Klinikai orvostudomány - orvos kategória \\ 2. Kísérletes orvostudomány - orvos kategória \\ 3. Orvostanhallgató kategória
}

A pályázatok díjazása

Az első helyezést elért orvosok 150-150 ezer forintot kapnak.

Az első helyezett orvostanhallgató 100 ezer forint dijjazásban részesül.

A pályamunkák benyújtási határideje: 2018. május 18. (péntek)

Orvostanhallgató pályázók az alábbi hat témakörböl szabadon választhatnak:

1. Képalkotó eljárások

2. Transzplantáció

3. Rákkutatás

4. Minimál invazív sebészet

5. Kísérletes sebészet

6. Genetikai diagnosztika

A pályázat formája: tudományos közlemény elvárásainak megfelelően megírt kézirat.

A pályamü terjedelme - mellékletekkel együtt - ne lépje túl a 25 oldalt.

A pályázó a pályaművét elektronikus formában nyújtsa be.

\section{A pályázatok benyújtásának feltételei}

1. A dolgozatot korábban nem publikálták.

2. A dolgozat nem sérti a Helsinki Deklaráció (1975, revízió 2008) előírásait.

3. A humán vizsgálatok az illetékes etikai bizottság jóváhagyásával történtek.

4. A laboratóriumi állatkísérletek a vonatkozó szabályok figyelembevételével történtek.

Az Orvosi Hetilap Szerkesztősége - a Regöly Alapitvány Kuratóriumának és Szakmai Bizottságának ajánlása után - vállalja, hogy a szakmai kritériumoknak kiemelkedően megfelelő pályázatok megjelenhetnek az Orvosi Hetilapban.

Orvosok hazai vagy nemzetközi folyóiratokban 2017-ben megjelent sebészeti tárgyú közleményeikkel pályázhatnak.

\section{További díjazások}

A Regöly Alapítvány díjkiosztó ünnepségén a kategóriák nyertesei mellett különdíjak átadására is sor kerül, amelyeket az Akadémiai Kiadó és a Semmelweis Kiadó ajánlott fel. Ezen kívül a legérdemesebb pályázatírók részt vehetnek és bemutathatják pályázatukat különböző szakmai konferenciákon, ha a Kuratórium és a Szakmai Bizottság erre azt érdemesnek találja.

A Regöly Alapítvány díjátadására Semmelweis Napon, 2018. június 29-én, 13 órakor a Semmelweis Egyetem Nagyvárad téri Elméleti Tömb Dísztermében kerül sor.

Központi e-mail cím: info@regolyalapitvany.hu

További információk: www.regolyalapitvany 